\title{
Evaluation of Surgical Outcomes in Different Hypospadias Types by HOSE Score
}

\section{Farklı Hipospadias Tiplerinde Cerrahi Sonuçların HOSE Skoru ile Değerlendirilmesi}

\author{
(D) Ekrem Güner, (D) Yusuf Arıkan \\ Bakırköy Sadi Konuk Training and Research Hospital, Clinic of Urology, İstanbul, Turkiye
}

What's known on the subject? and What does the study add?

Hypospadias objective scoring evaluation score is an objective and reliable scoring system that can be used to evaluate the results of hypospadias surgery.

\begin{abstract}
Objective: We aimed to present outcomes of hypospadias surgery with the help of the Hypospadias objective scoring evaluation (HOSE) system and to demonstrate the reliability of the HOSE.

Materials and Methods: Data of patients, who were operated for hypospadias in our clinic between January 2017 and March 2019 , were retrospectively analyzed. The parameters included demographic data, location of the meatus preoperative, postoperative complications, follow-up period, recurrence and postoperative HOSE score.

Results: A total of 46 patients were included in the study. The mean age of the patients was $8.5 \pm 5.4$ years. Fifteen patients had distal hypospadias, 13- subcoronal, 9- penile , 6- proximal and 3 had glanular hypospadias. Tubularized incised plate urethroplasty was performed in 35 patients, Bracka 2- stage repair in 6 patients and meatal advancement and glanduloplasty in 3 and, the onlay flap technique was used in 2 patients. The mean postoperative HOSE score was 14.6 \pm 1.7. The lowest HOSE score was found in patients with proximal hypospadias and the highest HOSE score was in those with glanular hypospadias (12.6 versus 15.6) ( $p=0.26)$. When HOSE scores of the patients were evaluated by a different physician, the mean HOSE score was found to be $14.5 \pm 1.7$. There was no significant intraobserver variation (Kappa score: 0.698$),(p<0.0001)$.

Conclusion: HOSE is an objective and reliable scoring system that can be used to evaluate the outcomes of hypospadias surgery. Keywords: Hypospadias, HOSE, Penile reconstruction
\end{abstract}

Öz

Amaç: Hipospadias cerrahisi sonuçlarını Hypospadias objective scoring system (HOSE) skorlama sistemi yardımıyla sunmayı ve HOSE skorlamasının güvenilirliğini ortaya koymayı amaçladık.

Gereç ve Yöntem: Kliniğimizde Ocak 2017 - Mart 2019 yılları arasında hipospadias nedeni ile opere edilen hastaların verileri retrospektif olarak incelendi. Incelenen parametreler hastaların demografik verileri, hipospadias lokalizasyonu, peroperatif ve postoperatif komplikasyonlar, takip süresi, nüks olup olmadığı, postoperatif HOSE skorundan oluşmakta idi.

Bulgular: Çalışmaya toplam 46 hasta dahil edildi. Hastaların ortalama yaşı 8,5 $\pm 5,4$ yıl idi. Hastaların hipospadias mea yerleşimleri, 15'i distal, 13'ü subkoronal, 9'u mid penil, 6'sı proksimal, 3'ü glanüler şeklinde idi. Hastaların 35'ine TiPU, 6 tanesine iki basamaklı Braca, 3 tanesine MAGPI ve 2

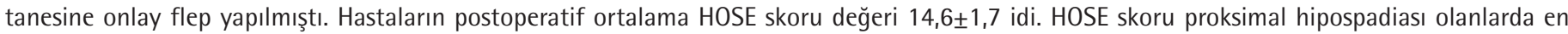
düşük iken glanüler hipospadiası olanlarda en yüksek idi, 12,6'ya karşın 15,6 ( $p=0,26)$. Farklı bir hekim tarafından aynı hastaların HOSE skorları

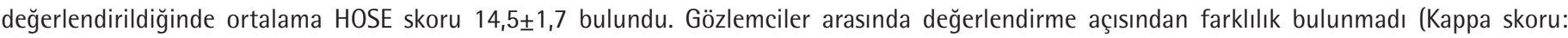
0,698), $p<0,0001)$.

Sonuç: HOSE skoru hipospadias cerrahisinin sonuçlarının değerlendirilmesinde kullanılabilecek objektif ve güvenilir bir skorlama sistemidir. Anahtar Kelimeler: Hipospadias, HOSE, Penil rekonstrüksiyon

Correspondence: Yusuf Arıkan MD, Bakırköy Sadi Konuk Training and Research Hospital, Clinic of Urology, İstanbul, Turkiye E-mail: dryusufarikan@gmail.com ORCID-ID: orcid.org/0000-0003-0823-7400

Received: 12.06.2019 Accepted: 15.09.2019

Cite this article as: Güner E, Arıkan Y. Evaluation of Surgical Outcomes in Different Hypospadias Types by HOSE Score. J Urol Surg 2020;7(1):54-57.

${ }^{\circ}$ Copyright 2020 by the Association of Urological Surgery / Journal of Urological Surgery published by Galenos Publishing House. 


\section{Introduction}

Hypospadias is a common congenital anomaly affecting one out of every 200 to 300 newborn males (1). Hypospadias surgery also aims functional recovery in addition to improving cosmetic appearance (2). More than 200 techniques have been defined for the surgical treatment of hypospadias. Some of these surgical techniques may have more complications (3). While a straight penis in erection, a meatus near the tip of the glans, ability to urinate in a standing position and being able to have sexual intercourse were found to be satisfactory in the evaluation of surgical success in the past, a functionally and cosmetically normal penis is aimed today. Evaluation of hypospadias surgery outcomes sheds light on future clinical practice (4).

Different scoring systems for assessment of hypospadias surgery outcomes have been suggested $(5,6,7,8)$. Surgical success and functional results of hypospadias surgery can be predicted with these scoring systems. Our aim in this study was to present the outcomes of hypospadias surgery performed in our study using the hypospadias objective scoring evaluation (HOSE) system and also to investigate the reliability of the HOSE.

\section{Materials and Methods}

After obtaining local ethics committee approval (protocol no. 2019-241; 20.05.2019), records of patients, who underwent surgery due to hypospadias in our clinic between January 2016 and March 2018, were retrospectively analyzed. The examined parameters were demographic characteristics, location of the maetus, peroperative and postoperative complications, follow-up duration, recurrence data and HOSE score in the postoperative $12^{\text {th }}$ month. The HOSE is a 5 - point scoring system evaluating meatal location, meatal shape, urinary stream, erection and presence of fistula. The minimum total score is 5 and the maximum is 16 points (9).

Seven out of a total of 55 patients who had hypospadias operation were excluded from the study due to previous hypospadias surgery and two others were excluded as they were over the age of 18 and the study covered 46 patients in total.

\section{Statistical Analysis}

IBM SPSS statistics for Mac version 21 (Chicago, IL, USA) was used for data analysis. While constant variables were given in mean \pm standard deviation, categorical variables were given in numbers and percentages. The Kolmogorov-Smirnov test was used to test normal data distribution. For the comparison of two groups, the Mann-Whitney $\mathrm{U}$ test was used for numerical data and chi-square tests were used for categorical variables. The One-Way ANOVA was used for comparing numerical data of more than two groups. Intraobserver reliability was measured using the kappa coefficient.

\section{Results}

A total of 46 patients were included in the study. The mean age of the patients was $8.5 \pm 5.4$ years. Fifteen patients had distal (meatus located on the glans or distal shaft), 13- subcoronal (just below the glans penis), 9- penile (in the midshaft), 6- proximal (at the penosocratal junction) and 3 patients had glanular hypospadias (meatus on the glans penis but not at the tip). Thirty five of the patients underwent tubularised incised plate urethroplasty (TIPU), 6 had Bracka 2- stage repair and 3 had meatal advancement and glanuloplasty incorporated (MAGPI), and the onlay flap technique was used in 2 patients. The average duration of catheterization was $12.1 \pm 4.6$ days. The average length of hospital stay was $3.2 \pm 0.9$ days and the average followup period was $22.7 \pm 15.6$ months. Recurrence was observed in 13 patients after $4.9 \pm 4.8$ months in average. Among the patients with recurrence, $10(76.9 \%)$ had urethrocutaneous fistula, 2 $(15.4 \%)$ had meatal stenosis and $1(7.6 \%)$ had wound infection.

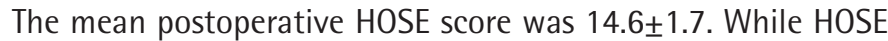
score was lowest in patients with proximal hypospadias, it was highest in patients with glanular hypospadias (12.6 vs 15.6) $(p=0.26) .11$ patients had a total HOSE score below $14(23.9 \%)$ and 35 patients (76.1\%) had 14 and above (Table 1 ).

When the groups with and without complication were examined, the mean HOSE score in the group with and without complication was $13 \pm 1.75$ and $15 \pm 1.05$, respectively $(p=0.106)$.

\begin{tabular}{|c|c|}
\hline \multicolumn{2}{|l|}{ 1) Meatal location } \\
\hline Distal - - - - - - - - - - - - - - - - - - - - - - - - - - & 4 \\
\hline Proximal glanular - - - - - - - - - - - - - - - - - - - - - - - - & \\
\hline 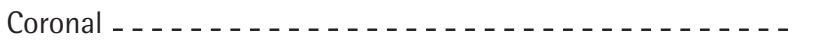 & 2 \\
\hline Penile shaft & 1 \\
\hline \multicolumn{2}{|l|}{ 2) Meatal shape } \\
\hline Vertica I - - - - - - - - - - - - - - - - - - - - - - - - - - - - - - & \\
\hline Circular - - - - - - - - - - - - - - - - - - - - - - - - & 1 \\
\hline \multicolumn{2}{|l|}{ 3) Urinary Stream } \\
\hline Single stream =- - - - - - - - - - - - - - - - - - - - - & \\
\hline Spray - - - - - - - - - - - - - - - - - - - - - - - - - - - - - & 1 \\
\hline \multicolumn{2}{|l|}{ 4) Erectile function } \\
\hline Straight & \\
\hline 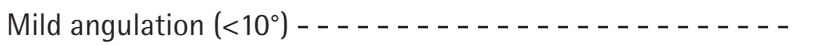 & 3 \\
\hline Moderate angulation $\left(>10^{\circ},<45^{\circ}\right)-\ldots-\ldots-\ldots-\ldots$ & 2 \\
\hline Severe angulation $\left(>45^{\circ}\right)--------$ & 1 \\
\hline \multicolumn{2}{|l|}{ 5) Fistula } \\
\hline None --------------------------------- & \\
\hline Single-subcoronal or more distal - - - - - - - - - - - - - & 3 \\
\hline 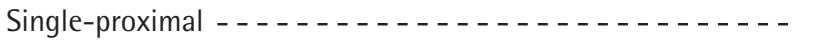 & 2 \\
\hline Multiple or complex -- - - - - - - - - - - - - - - - - - - & 1 \\
\hline
\end{tabular}


Although no statistically significant difference was detected in HOSE score between the groups, the lowest HOSE score was found in the complication group.

When the relationship between surgical method and HOSE score was examined, the mean HOSE score in 35 patients who had TIPU was $14.9 \pm 1.4$ while it was $13.5 \pm 2.3(p=0.167)$ in those who underwent surgery performed using other methods (MAGPI, onlay flap, Bracka). No significant difference was detected in HOSE score when surgical methods were compared but HOSE score was higher in TIPU group. The mean HOSE score was found to be $14.5 \pm 1.7$ when the HOSE scores of the patients were evaluated by a different doctor. There was no significant intraobserver variance (Kappa score: 0.698), $(p<0.0001)$.

\section{Discussion}

Hypospadias is one of the most difficult fields of urogenital reconstructive surgery. Many different techniques have been suggested for hypospadias repair. Complication rates, cosmetic appearance of the penis, urination and sexual functions, quality of life and psychosexual life should be considered when evaluating outcomes of hypospadias surgery. Today, different scoring systems are used for evaluating the surgical outcomes. Some of these are HOSE, hypospadias objective penile evaluation (5), Pediatric Penile Perception Score (6), Mureau (7) and Hadidi (8) scores (4). All these different scoring systems have their unique positive and negative aspects. In this study, we used HOSE to evaluate our hypospadias surgery outcomes.

HOSE score was defined by Holland et al. (9) in 2001. In an original study, randomly selected 20 patients were evaluated nearly 12 months after hypospadias surgery and HOSE score was given by four different observers (two doctor, one nurse and one relative of patient) to the patients and no significant intraobserver variation was observed (mean weighted kappa: 0.66). As a result, it was stated that HOSE score was a reproducible, objective outcome measure and independent of the preoperative severity of the defect (9).

In our study, no significant intraobserver variation of HOSE score was observed (Kappa: 0.69).

In a study made by Aulagne et al. (1) on 48 patients aged 20-35 years who had been operated due to severe posterior hypospadias in childhood, 27 follow-up patients were administered HOSE and a quality of life questionnaire prepared by the authors. Satisfaction rate in 21 patients with a HOSE score of 14 or above was $71 \%$, it was 51\% in patients with a HOSE score below 14 .

In another study including 55 patients, 34.5\% of the patients had acceptable outcomes with a total HOSE score of 14-16. HOSE score and uroflowmetry were suggested as simple, non- invasive and non-expensive techniques for evaluating longterm outcomes of hypospadias surgery (10).

In another study including 99 patients who underwent hypospadias repair using the meatal mobilization technique, $94 \%$ of patients reached the maximum of 16 points and $6 \%$ had 12-15 points on the HOSE symptom score (11). In our current study, the HOSE score of 14 and above in $76.1 \%$ of the patients may be explained by the fact that some of these patients had severe proximal hypospadias.

\section{Conclusion}

HOSE is an objective and reliable scoring system which can be used to evaluate outcomes of hypospadias surgery.

\section{Ethics}

Ethics Committee Approval: Ethics committee approval was received on 20.05.2019

Informed Consent: All patients had given written informed consent before the surgery for giving permission for the use of the collected data at any time.

Peer-review: Internally peer-reviewed.

\section{Authorship Contributions}

Concept: Y.A., E.G., Design: Y.A., E.G., Data Collection and/or Processing: Y.A., E.G., Analysis and/or Interpretation Y.A., E.G., Literature Research: Y.A., E.G., Writing: Y.A., E.G.

Conflict of Interest: No conflict of interest was declared by the authors.

Financial Disclosure: No financial support.

\section{References}

1. Aulagne MB, Harper $L$, de Napoli-Cocci S, Bondonny JM, Dobremez E. Longterm outcome of severe hypospadias. J Pediatr Urol 2010;6:469-472.

2. da Silva EA, Lobountchenko T, Marun MN, Rondon A, Damiao R. Role of penile biometric characteristics on surgical outcome of hypospadias repair. Pediatr Surg Int 2014;30:339-344

3. Prat D, Natasha A, Polak A, Koulikov D, Prat O, Zilberman M, Abu Arafeh W, Moriel EZ, Shenfeld OZ, Mor Y, Farkas A, Chertin B. Surgical outcome of different types of primary hypospadias repair during three decades in a single center. Urology 2012;79:1350-1353.

4. Springer A: Assessment of outcome in hypospadias surgery - a review. Front Pediatr 2: 2, 2014

5. Van der Toorn F, de Jong TP, de Gier RP, Callewaert PR, van der Horst EH Steffens MG, Hoebeke P, Nijman RJ, Bush NC, Wolffenbuttel KP, van den Heijkant MM, van Capelle JW, Wildhagen M, Timman $R$, van Busschbach JJ. Introducing the HOPE (Hypospadias Objective Penile Evaluation)-score: a validation study of an objective scoring system for evaluating cosmetic appearance in hypospadias patients. J Pediatr Urol 2013;9:1006-1016.

6. Weber DM, Schönbucher VB, Landolt MA, Gobet R. The Pediatric Penile Perception Score: an instrument for patient self-assessment and surgeon 
evaluation after hypospadias repair. J Urol 2008;180:1080-1084; discussion 1084.

7. Mureau MA, Slijper FM, Slob AK, Verhulst FC, Nijman RJ. Satisfaction with penile appearance after hypospadias surgery: the patient and surgeon view. J Urol 1996;155:703-706.

8. Hadidi AT. Functional urethral obstruction following tubularised incised plate repair of hypospadias. J Pediatr Surg 2013;48:1778-1783.
9. Holland AJ, Smith GH, Ross Fl, Cass DT. HOSE: an objective scoring system for evaluating the results of hypospadias surgery. BJU Int 2001;88:255-258.

10. Hussein NS, Samat SB, Abdullah MA, Gohar MN. Cosmetic and functional outcomes of two-stage hypospadias repair: an objective scoring evaluation and uroflowmetry. Turk J Urol 2013;39:90-95.

11. Seibold J, Werther M, Alloussi S, et al.: Objective long-term evaluation after distal hypospadias repair using the meatal mobilization technique. Scand J Urol Nephrol 2010;44:298-303. 